December 2014

\title{
Religiosity in Constitutions and the Status of Minority Rights
}

Brandy G. Robinson

Willamette University, brandygrobinson@gmail.com

How does access to this work benefit you? Let us know!

Follow this and additional works at: https://engagedscholarship.csuohio.edu/cecr

Part of the Bilingual, Multilingual, and Multicultural Education Commons, Comparative and Foreign Law Commons, Constitutional Law Commons, Critical and Cultural Studies Commons, Cultural History Commons, Dispute Resolution and Arbitration Commons, Gender, Race, Sexuality, and Ethnicity in Communication Commons, Human Rights Law Commons, International and Intercultural Communication Commons, International Law Commons, Law and Economics Commons, Law and Gender Commons, Law and Philosophy Commons, Law and Race Commons, $\underline{\text { Law and Society Commons, Peace and Conflict Studies Commons, Sexuality and the Law }}$ Commons, and the Social and Cultural Anthropology Commons

\section{Recommended Citation}

Robinson, Brandy G. (2014) "Religiosity in Constitutions and the Status of Minority Rights," Cultural Encounters, Conflicts, and Resolutions: Vol. 1 : Iss. 2 , Article 6.

Available at: https://engagedscholarship.csuohio.edu/cecr/vol1/iss2/6 


\title{
Religiosity in Constitutions and the Status of Minority Rights
}

\begin{abstract}
Minority rights and religion have never been topics that are simultaneously considered. However, arguably, the two have relevance, especially when combined with the topic and theory of constitutionalism. Historically and traditionally, minorities have been granted certain rights and have been denied certain rights under various constitutions. These grants and denials relate to cultural differences and values, arguably relating to a culture's understanding and interpretation of religion.

This article explores the relationship and status of minority rights as it relates to religiosity and constitutionalism. Essentially, there is a correlation between these topics and research shows where certain nations have used religion in a free, liberal manner, its citizens and visitors have less conflict and primarily are content and at peace and its economy have been at its best.
\end{abstract}

\section{Keywords}

religiosity, constitution, minority rights, human rights, equal rights, conflict, culture, global domestic

happiness 


\title{
Religiosity in Constitutions and the Status of Minority Rights
}

\author{
Brandy G. Robinson \\ Willamette University
}

\begin{abstract}
:
This article explores the relationship and status of minority rights as they relate to religiosity and constitutionalism. Historically and traditionally, minorities have been granted certain rights and denied others under various constitutions. These grants and denials relate to cultural differences and values and to a culture's understanding and interpretation of religion. Essentially, there is a correlation between these topics, and research shows that, in situations when certain nations have treated religion in a free, liberal manner, citizens and visitors have less conflict, and are primarily content and at peace, and the economy has been at its best.
\end{abstract}

Keywords: religiosity, constitution, minority rights, human rights, equal rights, conflict, culture, global domestic happiness

\section{Introduction:}

People precede the constitution (Lerner, 2011) and essentially come with the constitution, as a constitution is formed for purpose of social order. However, it is the author's opinion that when constitutions are wholly religious-based, particularly based on one religion, this notion that people precede the constitution is not the case, because religion or a practice becomes the focus, not the people. People evolve and religions do not; thus, constitutions that are wholly religious-based lack flexibility in modifying and ability to change with evolution.

Naturally, with religious-based constitutions, constitutional principles and society are at odds with traditions, norms and values, because religion within the constitution's framework determines the 
quality of life for its citizens. As such, this may create a subclass of individuals left behind and treated less than humanely, in particular affecting minority ${ }^{1}$ rights.

Ultimately, the progression of society depends on a flexible and secular $^{2}$ constitution that allows for a balance in religious freedoms and human rights, avoiding conflict and dilemma of religious freedom and overall human rights. In fact, there has long been international recognition of this global obligation in balancing rights in order to ensure human rights for everyone (Universal Declaration of Human Rights). This paper explores types of regimes, whether these regimes give credence to religion, and how these regimes and the constitutions correlate with minority rights.

\section{Religiosity and its connection to government:}

\subsection{Early Recognition of Religion in Society and Government:}

Religion has been a strong force in state formation. This is generally evidenced in the Islamic expansion into Europe. Additionally, the colonial expansions in certain parts of Europe, Africa, and the Americas were successful due to the help of the church, as the church provided humanitarian assistance and even gradually converted regions to certain doctrines and ways of thinking. Latin America experienced similar shifting in religious practice and dominance, which created an eventual integration into virtually all areas of society. In past years, Sudan has had a similar fate with the help of Muslim Brotherhood and Sufi organizations in the North (Bax, 1987).

Depending on whom one asks or the body of research, the first documented account of religious influence in government can vary (Kohlenberger, 2005). In fact, accounts may also vary as to the first religious war (Universal Declaration of Human Rights). The earliest documented accounts of Christian and Islamic religious influence on government dates back to the biblical era of Abraham and the land of Canaan, where a covenant was made between God and Abraham

\footnotetext{
${ }^{1}$ Minority, in this context, includes all minorities (religious, ethnic, nationality, age, gender, sexuality orientation, disability, etc.). In many ways, it is viewed as analogous to human rights issues and should be viewed in this manner because minority rights issues are human rights issues. ${ }^{2}$ The intent of this paper is not anti-religious or anti-spiritual and is not to prove or disprove what religion is the most effective or the best for society. The focus is to show how constitutions based in religion have contributed to the societal divide, contributing to conflict and hatred among cultural groups, and correlating with lower quality of life and economic productivity.
} 
(Kohlenberger, 2005. At that time, the concept of God and religion were one, because all things were believed to derive from one exclusive source, God (Kohlenberger, 2005).

Over time, this covenanted understanding diminished, but ancient societies viewed religion as critical to social order. Because of this, religious conflicts permeated existence, primarily because of a lack of agreement on what religion (or which god) was the rightful one (Kohlenberger, 2005). Ultimately, this resulted in tribal and religious wars; thus, whoever won the conflict had the advantage of placing his religion as the dominating force and rule over society usually done via forced conversion (Pearse, 2007). Forced conversion was a widely used tactic in converting societies to a different philosophy and norm. 3

Many people can make the argument that the same holds true today, especially in the Middle East where significant changes are occurring (Fadel, 2014). Several Islamic countries are wrestling over what constitutional provisions and state actions work the best for governance, while still respecting Islamic law (Lombardi, 2013). However, the Christian faith was not without internal conflict, since religious wars eventually ensued within the Christian faith between Catholicism, Catharism, Eastern Orthodoxy, and Protestantism (Kohn, 2007).

Today, Islam, Christianity, Judaism, and Hinduism are considered the largest conventional religions in the world (http://www.adherents.com/Religions By Adherents.html ). Still existing, however, are numerous minority religions. One can imagine the differences in religious doctrines that existed centuries ago and now. These doctrines, especially if coupled with governmental mandates influenced by a sole religion, can create societal norms and standards that vary drastically.

Adherence to a doctrine could create a struggle if the doctrine does not fit or work for an individual, and/or a religion is too rigid and unaccepting of non-conforming behaviors or people. This is the case today as many minority groups seek protection and humane treatment against rigid and unaccepting religious doctrines based in government. They seek asylum in developed and progressive nations.

\footnotetext{
${ }^{3}$ Pearse, M. (2007). The gods of war, pp. 43-47. Nottingham: Inter-Varsity Press. History records the Roman-Persian Wars as one of the longest conflicts in history, during which the Eastern Roman Empire was conquered and the Muslim faith was the controlling religion. This dominance eventually led to the Byzantine-Muslim Wars between Christians and Muslims from the 600s to 900s. Nicolle (1984) writes about the Saxon Wars, which occurred in the 8th and 9th centuries. These, again, involved the compulsory conversion of pagans to Christianity by use of persecution and torture. See D. Nicolle, Arthur and the Anglo-Saxon wars (Osprey Publishing, 1984).
} 


\subsection{Ritual Practice in Religion and Government:}

Whether society or government views certain practices in this manner, there is a particular procedural practice (often termed ritual) in some customs and norms. The definition of "ritual" may vary. The definition of ritual in this context is not a mystical view of ritual, but one of a practical context. One must qualify this word or phrase as to whom, when, why, and how, leading to a subjective meaning of "ritual" (Bjerknes Aune \& DeMarinis, 1996). The result is that there is no exclusive meaning (Bell, 2009). To provide context on this term, say Bjerknes Aune and DeMarinis, ritualistic practice may be the closest and most accurate way in defining ritual.

Ritualistic practice is a strategic way of acting, which may result in a pattern of actions involving objects, gestures, and traditions. This practice frequently aligns with religion, particularly organized religions, for praising a central religious figure. It has been an unrecognized element (as many people and societies simply overlook this concept). Yet, it is a common connection among many governments and religions around the world. Whether this is intentional in all governmental structures is unclear. Yet, governments around the world have realized the benefit of ritualistic practice of religion in some shape or form, because such practices help in controlling chaos and creating social norms. 4 This is how ritualistic practice is so important and relevant in the context of constitutions and governance.

Rituals serve many purposes: Legitimacy, solidarity, organizational integration, and inculcation of political beliefs (Kertzer, 1988). Centuries ago, many governments believed it helped in uniting a particular image or theme. No religious or state organization can exist without such symbolic representation. Ritualistic practice creates the image or embodiment with which people associate. Symbolic items or representation can be seen in contemporary constitutions. These can be clothing, songs, currency, or flags that indicate a certain affiliation or association with a state or religious organization (Kertzer, 1988).

Several examples of ritualistic practice have existed throughout history. Assigning a day of faith or allegiance was a common ritualistic

\footnotetext{
${ }^{4}$ Over time, ritualistic practice can become a political aspect in government; many leaders have seen an undeniable benefit in using religious ritualistic practice to gain political power. One example is Emperor Napoleon Bonaparte I of France (see above).
} 
practice for many governments (Kertzer, 1988). One such example includes the Day of Faith in 1935, which was to show allegiance to the fascist Italian regime (Kertzer, 1988). Other examples include South Africa's replacing certain days once associated with British Monarchs: The Cape of Good Hope Decoration replaced Victoria Cross and Settlers' Day, and the Day of the Covenant replaced Empire Day and the Queen's Birthday (Kertzer, 1988).

Other areas of Africa retained the British influence (Kertzer, 1988). For instance, British influence was significant in Swaziland's governance and stability after it gained independence. Swaziland continued to honor this influence by continuing the ritualistic practice singing the anthem, "God Save the Queen," and using royal garbs and other items and gestures (Kertzer, 1988).

Islamic cultures also have ritualistic practices. In many traditional Islamic nations, the constitutional framework resembles the principles of the Quran.5 Religious values are at the core of those Islamic nations, including regulation of the political organs of society and the social behaviors and norms of its citizens. ${ }^{6}$ For instance, political leaders and judges may be chosen according to the Islamic faith and must follow as well as pass judgment based on Islamic law.7 Some nations may require women to wear headscarves, as this is viewed as modest and private under Islamic interpretation of the Quran. ${ }^{8}$ Ritualistic practice was also prevalent among historic leaders and can be viewed as political, because many leaders gained political power in this manner (See Kertzer, note 24, p. 181).

For example, Emperor Napoleon Bonaparte I of France used ritualistic practices when he took over Italy and expropriated property, and, at the same time, the church lost dominance. Napoleon realized that the church was the only entity that united the people, and it had the most dominance in the territory. Therefore, he used the church's ritual rites for

\footnotetext{
${ }^{5}$ This may mean something different to each Islamic nation, as the Islamic interpretation is not the same in each nation.

${ }^{6}$ The Holy Quran, Surah 21: 29. This could be embodied in the phrase and how certain Islamic nations interpret the Quran: "This your community is a single community, and I am your Lord, so worship Me"

${ }^{7}$ The Holy Quran, Surah 21:105. "Verily My righteous servants shall inherit the earth." See also the Holy Quran, Surah 28.5: "And we wish to show favor to those who have been oppressed upon earth, and to make them leaders and the inheritors."

${ }^{8}$ The Holy Quran, Surah 24:30. "Tell the believing men to lower their gaze and be modest." Interpretation varies among Islamic nations, as each nation may not take the same Islamic interpretation. Therefore, some nations may be strict in requiring females to conform to certain norms and values, whereas others are not. The key piece is the interpretation and how this interpretation in provided in an Islamic constitution.
} 
his purposes in gaining support for his reign by ordering the Minister of Religious Affairs to demand archbishops and bishops to declare obedience to Napoleon. This dominance led to a day named after Napoleon providing deference to him and idolizing him, (Kertzer, 1998).

Punishment or the threat of punishment was frequently implemented to gain compliance from others (Kertzer, 1988). Today, we see this ritualistic practice is not as extensive and is not a conscious practice. Yet, this practice has helped in bridging the past practices and values to today's society. Ritualization had multiple purposes, but the main purpose was to provide symbolism of power and importance. Essentially, the appearance of power and importance would be persuasive (Kertzer, 1988).

David Kertzer (1988), a respected scholar in anthropology, highlights the fact that Machiavelli, as a political philosopher and adviser, admitted that men made judgments based on appearances rather than reality. In fact, Machiavelli believed that this was one of the few ways of effective leadership, so much so that he advised leaders to keep the people occupied with festivals and shows. Leaders took this advice well;

overcoming appearance versus reality later became an issue in and of itself (Kertzer, 1988).

Kertzer (1988) also suggests that the symbolic nature of rituals in society, religion, and government is hidden; yet, representation and ritualistic practice create a very convincing world. He states, in particular, that rituals and symbolisms are ways in which to deflect from reality of a situation and convince us that we are viewing the way it really is. He states it is hard to argue against a flag, song, etc., when one does not have one's own.

\subsection{International Policies on Religion:}

The definition or meaning of religion or belief varies from individual to individual and nation state to nation state. The definition in itself has been a source of debate and conflict for many courts and societies, as some areas of the world may not respect certain religions or beliefs, or the lack thereof. The world realized religion's impact from World War II, in particular from Hitler's reign, sparking immediate constitutional reform. 9

\footnotetext{
${ }^{9}$ Backer, L.C. (2007-2008). God(s) over constitutions: International and religious transnational constitutionalism in the 21st century, p. 27; Mississippi College Law Review, p. 11. During World War II, Germany and Japan took on forms of government that included a totalitarian and militaristic approach. Germany and Japan used religion as a basis for dominance of race, ethnicity, and other cultural classifications. Before the Allies won World War II, Germany and Japan were able to create laws that legitimized cruelty and military barbarism.
} 
Reforms involved international development to protect against human rights violations or any discriminatory acts of certain cultural classifications, such as religions or beliefs, or the lack thereof.

Development of reforms led to some international understanding of moral and ethical obligations in which no nation could opt out, resulting in the desired effect of an international secular uniformity in constitutions. This effort led to disbandment of the League of Nations and, in 1945, the creation of the United Nations (Backer, 2008).

The United Nations formulated several international protocols regarding the protection of human rights, including those that addressed religion and belief. First, the Universal Declaration of Human Rights provides equal protection and rights without distinction and against discrimination based on religion among other rights. This influential declaration accompanied other international mandates that adopted similar language. ${ }^{10}$ Second, the International Covenant on Civil and Political Rights provides similar language as the Universal Declaration of Human Rights and calls for state members to ensure said rights and protections of individuals within its territory. ${ }^{11}$

The third international protocol is the Declaration on the Elimination on All Forms of Intolerance and of Discrimination Based on Religion or Belief. This protocol is, by virtue, broad in terms of implementation and allows broad protections for individuals in member states. ${ }^{12}$

These protocols have been influential in the European and African regions setting forth various mandates in respecting, protecting religious freedoms, implemented, and enforced by European member states and African nations functioning within the regions. ${ }^{13}$

\footnotetext{
${ }^{10}$ The Universal Declaration of Human Rights. Articles 1-3, 5, 7, 16, \& 18-20. This document could be the most important international document, but only less than $5 \%$ of the world knows about this document. Therefore, it has not been hugely successful as many nations still commit similar atrocities that this document protects against. In essence, this document and international effort in securing human rights are a work in progress. See also J. Healey, Happy birthday, Declaration of Human Rights, Huffington Post, December. 8, 2008, at http://www.huffingtonpost.com/jack-healey/happy-birthday-declaratio_b_149246.html.

${ }^{11}$ International Covenant on Civil and Political Rights. Articles 2, 4, 18, 24, 26 \& 27.

${ }^{12}$ Declaration on the Elimination on All Forms of Intolerance and of Discrimination Based on Religion or Belief. Member states commit to ensure these guarantees and protections within its territories.

${ }^{13}$ Appendix D: Regional Organizations' Religious Freedom Commitments. See http://www.state.gov/j/drl/rls/irf/2008/108547.htm
} 


\subsection{Domestic Application of Religious Principles and Norms:}

Despite having international protocols that clearly protect religion, court systems around the world have struggled with defining religion and belief. Before World War II, Muslim countries developed a unique method in settling the conflicts between human rights and constitutionalism. After World War II, Muslim countries defined more finely this effort (Backer, 2008, p. 40-41). This involved recognition of global secular principles or norms common among the family of nations, while still recognizing the Islamic religious background (Backer, 2008).

However, the European area may have accomplished the most success in this area by its harmonization and uniformity of union rules. The belief aspect has been problematic, because it is not always clear what constitutes a belief. Most notably has been the European Court of Human Rights, one of the most successful human rights courts in combatting human rights violations, which has been in the forefront in defining religion and belief and providing excellent guidance on how this issue should be handled.

The European Court of Human Rights provided guidance that a philosophical belief or religion must be one that: (1) is genuinely held; (2) is a belief and not an opinion; (3) attains a certain level of cogency, seriousness, cohesiveness, and importance; and (4) is worthy of respect in a democratic society and does not violate human dignity. 14 If the seriousness of the religion or belief is irrelevant, the court has signaled, some minority beliefs or religions may be left behind. ${ }^{15}$ Naturally, this is the case in other parts of the world in which minority religions and beliefs (and minorities as a whole) are left insufficiently protected under the law with the lack of sufficient and enforced protections. Such situations have been at the core of many cultural clashes. ${ }^{16}$

\section{Types of state-religion regimes:}

In order to simplify the state regime analysis, a common classification of state regimes is presented in this section. ${ }^{17}$ This encompasses four categories: (1) religious states with institutionalized systems; (2) religious states with recognized official religions; (3) secular

\footnotetext{
${ }^{14}$ Campbell and Cosans v. UK (1983). No. 7511/76, 7743/76, Series A60.

${ }^{15}$ cf. $X v U K$ (1977). No. $7291 / 75$, D.R. 11 p. 55.

${ }^{16}$ Indonesia: Rights rollback for religious minorities, women (2014). Human Rights Watch, accessed January 22, 2014, at http://www.hrw.org/news/2014/01/21/indonesia-rights-rollbackreligious-minorities-women

${ }^{17}$ For purposes of this discussion, one example from each regime type will be analyzed.
} 
states; and (4) anti-religious states (Lerner, 2011). The statistical results indicate that all regimes are struggling with cultural and social balance; yet, minorities may fare better in regions that are not hostile towards religious freedom and institutionalize an even hand relative to religious and personal belief systems.

\subsection{Religious States with Institutionalized Systems ${ }^{18}$ :}

Religious states with institutionalized systems encompass territories in which there are religious laws and courts governing those religious laws. Frequently, those laws dictate social norms and values. Current day examples of nation states utilizing this type of regime are Iran, the kingdom of Saudi Arabia, and Sudan (Kuru, 2009). In this section, Iran is the focus.

\subsubsection{Iran:}

In 1978, Iran experienced the beginning of a revolution that eventually removed the Pahlavi monarchial regime in 1979; this shifted its constitutional framework (Horowitz, 2010). In fact, 98.2\% of Iranian people voted for this framework. ${ }^{19}$ The 1979 Constitution would be the foundation of the new Iran with a new ruler, the Ayatollah Khomeini. ${ }^{20}$

The new Iranian form of government resembled a traditional Islamic view of the world: An Islamic republic. The constitutional language embodies Shi'a Islamic tradition and the religious language of the Quran. The Quran is cited at least 14 times throughout the Iranian constitution (Horowitz, 2010), providing phrases ${ }^{21}$ such as, "In the Name of Allah, the Compassionate, the Merciful. We sent aforetime Our apostles with clear signs, and sent down with them the Book and the Balance that men may uphold justice .... (57:25)"

This traditional view involved removing foreign ideological influences and secular ideologies, thus making the Quran, Islamic law, and religion the core of society. This view highlighted the fact that government did not derive from the interests of the people, but rather that government resembled a common faith focusing on Allah. Article 2 of the 1979 Iranian

\footnotetext{
${ }^{18}$ Kuru, A.T. (2007). Passive and assertive secularism: Historical conditions, ideological struggles, and state policies toward religion. World Policy, 59, 568-594.

${ }^{19}$ Constitution of the Islamic Republic of Iran: October 24, 1979 (as Amended to July 28, 1989) (Iran [ir]) (2010). Oxford Constitutions of the World.

${ }^{20} \mathrm{Ibid}$. This new constitution was adopted on or about October 24, 1979 and amended on or about July 28, 1989.

${ }^{21}$ See Constitution of the Islamic Republic of Iran, supra note 74.
} 
Constitution provides that the Iranian system should comprise One God, as stated, "There is no god except Allah."

In fact, many rights and passages in the Iranian Constitution refer to (or at least interpret) the Quran. There are several safeguards protecting women and children, but the reality of the situation may be drastically different, as it is illustrated in the subsequent sections of this paper. It could be argued that the Iranian Constitution violates numerous rights as detailed in the Universal Declaration of Human Rights.

The Constitutional view pervaded all areas of society. For example, this view required that the political infrastructures and institutions become the responsibility of those of Islamic faith who possessed the necessary qualifications and were established (or viewed) as leaders among Islamic people. ${ }^{22}$ The Army of the Islamic Republic of Iran and other Iranian armed forces were responsible for maintaining the territory against enemies of the Islamic faith, while also spreading Islamic faith around the world. ${ }^{23}$

Additionally, the judiciary, although independent, was responsible for instituting Islamic justice through judges knowledgeable in Islamic law. ${ }^{24}$ The executive and legislative branches of government also enforced and created laws in accordance with Islamic law and tradition. ${ }^{25}$ This structure meant that media could not communicate any propaganda against Islamic principles or information that would otherwise be viewed as inconsistent with Islamic culture. As a result many state-run media outlets came into being. 26

The belief was that the Iranian revolution would continue to progress in this notion with the use of the new 1979 Iranian Constitution that is held to provide everything necessary for establishing one world community and liberating the poor and oppressed. ${ }^{27}$ The Iranian government's goal was to provide its citizens with opportunities to satisfy

\footnotetext{
${ }^{22}$ Ibid. The 1979 Iranian Constitution frequently points to Quranic verses in support of this view and tradition. This is consistent with most governmental Iranian processes. These verses include the following: "Verily My righteous servants shall inherit the earth" [21:105] and "And we wish to show favor to those who have been oppressed upon earth, and to make them leaders and the inheritors" [28:5]. Also found is the following: "The direction of [public] affairs is in the hands of those who are learned concerning God and are trustworthy in matters pertaining to what $\mathrm{He}$ permits and forbids" [Tuhaf al- "uqūl, p. 176]

${ }_{23}$ Ibid.

${ }^{24}$ Ibid.

${ }^{25}$ Ibid.

${ }^{26}$ Ibid.

${ }^{27}$ Ibid. This is the Iranian view, as in accordance with the Quranic verses: "This your community is a single community, and I am your Lord, so worship Me" [21:92] and "He removes from them their burdens and the fetters that were upon them" [7:157]
} 
basic needs. Iran made this belief the core of all things, with the Islamic religion being the driving force including with family values. Yet, this did not necessarily indicate a prosperous and conflict-free society, because the economy was viewed as a means and not an end. ${ }^{28}$

\subsection{Religious States with Recognized Official Religions ${ }^{29}$ :}

States with populations espousing established religions often recognize an official religion. These regimes do not make the official religion the focal point of their institutionalized systems (e.g., legal and judicial systems). Examples of these states include England, Denmark, and Greece (Kuru, 2007). Denmark is the example used in this section.

\subsubsection{Denmark:}

Denmark has a unique history, unlike some counterparts and surrounding nations, because it is a kingdom. Reports in recent years have shown that the majority of its people are content with the current state of governance, including the fact that Christianity is the dominant religion in Denmark. Outside of the established Lutheran faith (also known as the Established Church in Denmark) and the large migration of Islamic believers into Denmark, there are also small minorities of religious groups from faiths including Judaism, Buddhism, Baptist, Roman Catholicism, Mormonism, and Baha'i. ${ }^{30}$

Despite Denmark's constitutionally established religion, the Danish Constitution provides at least four religious protections. The first protection is noted in Article 67 of the Danish Constitution, which assures a general freedom of worship as long as the practice does not go against "good morals or public order." 31 Under Article 68, there is no requirement of the individual to contribute to the Established Church unless the Lutheran faith is his or her religion. ${ }^{2}$

\footnotetext{
${ }^{28}$ Ibid.

${ }^{29}$ See Kuru, supra note 70.

${ }^{30}$ These groups are protected under the law due to the vast protections under the law for not only religious belief but personal belief.

${ }^{31}$ Denmark Constitution $\S 67$. "Citizens shall be at liberty to form congregations for the worship of God in a manner according with their convictions, provided that nothing contrary to good morals or public order shall be taught or done." The terms "good morals or public order" is not clearly defined in the constitution.

${ }^{32}$ Denmark Constitution $\S 68$. "No one shall be liable to make personal contributions to any denomination other than the one to which he adheres." In fact, the Established Church was the only faith to receive state funding, while other faiths receive contributions from the public.
} 
Under Article 70, Denmark provides a right to freedom of religion. 33 This right goes a step further in stating that this right cannot be denied due to race or religious distinctions. 34 Article 71 extends protections against religious persecution or imprisonment. 35 Additional individual rights are protected under Part 8, which plays a part in Denmark's success in balancing the interests and equities of the people and nation, thus satisfying the international protocols such as the Universal Declaration of Human Rights. ${ }^{36}$

Another unique factor is that the branch of Christianity in Denmark is the Evangelical Lutheran Church, established under Denmark's Constitution in Article 4.37 Additionally, the king must be a member of the Evangelical Lutheran Church, as specified in Article 6.38 These stipulations make official that Denmark's established religion is Christianity. 39

Despite the established religion of Lutheranism and the constitutional rule that the king must be a member of the Established Church, the Danish people enjoy a secular society and a seemingly secular government. $4^{\circ}$ Today, Denmark is a unique parliamentary democracy with legislative powers shared between the monarch and parliament. ${ }^{41}$ Some of this development could be attributed to the nation's membership in the European Union, which requires certain directives and universal and uniform community standards among member states.

However, another unique constitutional characteristic or variance is that Denmark is currently ruled by a female monarchial head, Queen

\footnotetext{
${ }^{33}$ Denmark Constitution $\S 70$. "No person shall by reason of his creed or descent be deprived of access to the full enjoyment of civic and political rights, nor shall he escape compliance with any common civic duty for such reasons."

${ }^{34}$ Ibid.

${ }^{35}$ Denmark Constitution $\S 71$. “(1) Personal liberty shall be inviolable. No Danish subject shall, in any manner whatsoever, be deprived of his liberty because of his political or religious convictions or because of his descent."

${ }^{36}$ Denmark Constitution provides for individual rights under Part 8. This includes the right to personal liberty, right against unreasonable search and seizure, right to property, right to free and equal access to trade, right to free public education, freedom of speech, association and assembly. The constitution also abolishes all privileges by legislation attached to nobility, title or rank.

${ }^{37}$ Denmark Constitution $\S 4$. "The Evangelical Lutheran Church shall be the Established Church of Denmark, and as such shall be supported by the State."

${ }^{38}$ Denmark Constitution, § 6. "The King shall be a member of the Evangelical Lutheran Church."

${ }^{39}$ But, this practice is restricted to the highest level of government such as the monarchy as other key political and governmental officials have been known to be atheists or non-Christian yet still have held office.

${ }^{40}$ Nergelius, J. edited by Max Planck Institute (2007). The Kingdom of Denmark: Introductory note, Oxford constitutions of the world.

${ }^{41}$ Ibid.
} 
Margrethe II.42 Males, traditionally and constitutionally, held this rank until a constitutional change prior to Margrethe's ascension. Therefore, her role cannot be underestimated. Even though she is not elected and serves primarily as a figurehead, her influence remains important in domestic and international arenas.

The success of Danish government may be interpreted as deriving from its membership in the European Union (EU) and the balance between the minority parliamentary parties and other interests. With membership in the European Union (EU), Denmark is required to implement certain EU regulations, creating a harmonization of certain industries and rights. Therefore, Denmark frequently endorses the human rights protocols in the EU.

Denmark's constitutional structure is similar to most European structures because it establishes similar court systems where cases can be tried in two instances: District court and High Court. Denmark is a member of the United Nations; this too confirms its willingness and general respect in protecting its citizens and their rights.

Yet, such balance was not always easy; Denmark's constitutional procedures can be problematic, with its unique parliamentary and monarchial process. Denmark's constitutional issues (especially relative to human rights) were resolved over time after joining the EU, where the treaty among the EU Member States and the goals and aims in harmonization helped in creating the uniformity and consistency necessary in Member States, thus avoiding many pitfalls experienced in non-EU Member States.

\subsection{Secular States43:}

Secular states are opposite of all state regimes previously listed, because they do not recognize an official religion. A secular state's legal and judicial systems are neither controlled nor institutionalized by a religion. The most common examples include France and Turkey (Kuru, 2007).

\footnotetext{
42 The Danish monarch. http://kongehuset.dk/english. With the changes in Danish Constitution permitting females to ascend to the throne if the female had no brothers, Queen Margrethe II became heiress presumptive.

${ }^{43}$ This research dealt with nations outside the U.S.; thus, the U.S. is not mentioned here. However, it may be noted that the U.S. is a secular state having a secular constitution.
} 


\subsubsection{France:}

France does not recognize a single religion; it takes a secular approach.44 This is indicated from the Constitution of the French Republic, Article 1, as it reads:

France shall be an indivisible, secular, democratic and social Republic. It shall ensure the equality of all citizens before the law, without distinction of origin, race or religion. It shall respect all beliefs. It shall be organized on a decentralized basis. 45

The secular principle is highlighted throughout French constitutional history. The first article or principle underscores France's intent and the significance placed on the requirement of separation of church and state and freedom of belief. Yet, the article still observes the government's obligation to satisfy the Universal Declaration of Human Rights. As such, France neither endorses nor subsidizes any religion, requiring strict adherence to this principle in all public places and institutions. 46

France's stance on secularism did not come without debate. Religious minorities have progressively argued for more protections in public institutions. In fact, these arguments became relevant in public educational institutions. Students, claiming a constitutional right in public educational institutions, refused to attend biology and physical education classes because of religious beliefs, and others began wearing religious clothing items (i.e., headscarves and other religious symbols).

To quell this constitutional debate, France passed the Act of Secularity and Conspicuous Religious Symbols in Schools, prohibiting conspicuous religious symbols in public primary and secondary schools but not universities. 47 The legislation left room for other religious items in the public primary and secondary schools as well as interpretation of additional religious freedoms in universities.

\footnotetext{
${ }^{44}$ Constitution of the French Republic: September 28, 1958 (as Amended to July 23, 2008) (France [fr]), Oxford Constitutions of the World (2008).

${ }^{45}$ Ibid.

46 There are limited exceptions in which France funds religious education. This is discussed in the latter paragraphs of this section.

${ }^{47}$ Ibid. citing Loi n ${ }^{\circ}$ 2004-228 du 15 mars 2004 encadrant, en application du principe de laïcité, le port de signes ou de tenues manifestant une appartenance religieuse dans les écoles, collÈges et lycées publics, Journal officiel No. 65 of March 17, 2004, p. 5190.
} 
France takes an assertive stance on secularism. $4^{8}$ Essentially, there is no public discourse on religion in French public institutions (Kuru, 2007). Despite this stance regarding religion and a clear prohibition against funding religion, France is not all negative towards religion (Kuru, 2007). In fact, France funds private religious schools, but only with the understanding that France could assume certain state controls over the school (Kuru, 2007).

However, France's history did not begin with such neutral standing (Brémond, 1936). Over time, France found that a secular state promised the better balance of societal interests with little conflict in certain areas. The current secular thinking was established after a long history of religious influence. After Romans dominated France, the medieval period brought about wars of religious intolerance (Kuru, 2007). These wars were followed by the Hundred Years War, The Wars of Religion between Protestants and the Catholic Church, and the French Revolution (Kuru, 2007).

Contemporary France resembles a secular society that strives to avoid the religious wars and struggles of its past, which is a common theme among many nation states seeking to avoid similar struggles of their past (Kuru, 2007). Today, France is a multiparty constitutional democracy (U.S. Department of State, 2013).

\subsection{Anti-Religious States49:}

Most nation states fall into one of the above three regimes. Yet, the past histories of certain nations have indicated an anti-religious stance. Anti-religious states are sometimes referred to as atheist state regimes. These regimes show extreme hostility towards religion. A few examples include China, North Korea, and Cuba (Kuru, 2007). In recent years, China, North Korea, and Cuba have moved from an anti-religious stance to a secular stance or a state-recognized religious stance. $5^{\circ}$ Consequently,

\footnotetext{
${ }^{48}$ See Kuru, supra note 70, at 572 and 581. There are two types of secularists: Assertive and passive. "The assertive secularists aim to confine religion to the home and to the individual's conscience, while the passive secularists try to allow a public role for religion. In short, passive secularists want to liberalize secularism in France with a new emphasis on individualism and multiculturalism."

${ }^{49}$ See Kuru, supra note 70.

${ }^{50}$ Many anti-religious nations have shared a similar ideological stance of Marxism and Leninism. Throughout history, this stance has been shown to be ineffective. Questions can be raised as to why certain nations such as Cuba have changed its anti-religious stance, which could possibly relate to the need for economic assistance. In many instances, most institutions that may assist a nation or territory may not feel comfortable with donating or assisting a nation that does not believe in morale value or a religious value.
} 
there is not only an anti-religious stance commonality among the three states, but also each nation state has a complex economic and political history.

\subsubsection{North Korea:}

North Korea is hostile against religion, and religion is not mentioned in any facet of its society unless it is on an individual basis and in private. One could easily find that minorities in this region are suppressed. Thus, this calls into question whether its citizens and visitors are allowed to practice religion; if so, the question becomes what religion could be practiced without state opposition.

Additionally, North Korea has shared a rigid and hostile history with the rest of the world..$^{1}$ Much of this hostility results from its history and longing for independence (or dominance) in the global sector (Grote, 2008). Currently, under leader Kim Jong-un (BBC News, 2011) North Korea's governmental stance is socialistic, stemming from MarxismLeninism (Grote, 2008). The North Korean Constitution and government underwent several changes, but the Constitution is primarily focused on economic rights, culture, and politics rather than individual rights and democracy (Grote, 2008).

Despite its name of Democratic People's Republic of Korea, there is no democratic government. The territory's constitution is a "political manifesto" and not a constitutional document setting forth limits, which balances the political power, individual rights, and a democratic government (Grote, 2008).

The North Korean constitution provides for "freedom of religious belief" and may create accommodations for some established religions, but religious practice or belief is virtually non-existent. $5^{2}$ Many North Koreans are reluctant to pass personal religious practices on to the next generation for fear of persecution and death.53 This, along with other human rights violations, prompted many people to defect to other regions. 54

\footnotetext{
${ }^{51}$ Grote, R., edited Max Planck Institute (2008). The Democratic People's Republic of Korea: Introductory note, Oxford constitutions of the world. The Korean territory divided into two territories after the World War II, with the U.S. occupying the southern region and the Soviet Union occupying the northern region. Eventually, North Korea assumed the character and influence of the Soviet Union.

${ }^{52}$ See Religious Intolerance and Oppression in North Korea at http://www.religioustolerance.org/rt_nkor.htm

${ }^{53} \mathrm{Ibid}$.

${ }^{54}$ Ibid.
} 
In past years, there have been defectors from North Korea lured back to North Korea via fake churches set up in certain regions such as China. In most recent months, there has been huge concern for the state of human rights in North Korea, begging the question whether the nation is volatile of the Universal Declaration of Human Rights. 55

\section{Minority rights, economic development and religiosity in constitutions:}

This section highlights a small segment of the minority rights issues occurring globally and discusses how economic development pertains in certain nation states. This section particularly highlights whether nation states that are hostile towards religion have unstable or resistant economies and/or cultural differences and conflicts that limit happiness and human rights. This section is limited to certain rights that are the most severe or unique to a particular region or nation.

\subsection{Religious Market Theory:}

Religion is virtually ingrained in many societies. Barro and McCleary, in 2005, noted, "Among 188 countries, 72 had no state religion in 2000, 1970, and 1900; 58 had a state religion throughout; and 58 had 1 or 2 transitions." Nearly 14 years later, the landscape is much different, with the increase of official state religions (or state-sponsored and/or funded religion), there is a strong possibility that theories such as a religiousmarkets $5^{6}$ are at play.

So, what is the religious market theory? It has been described as a supply and demand indicator in many intellectual contexts. ${ }^{57}$ Essentially, churches are viewed as companies selling goods (Hadden, 1995). In theory, it is said that people like religion because it is compensatory (i.e., it allows for some level of benefit or reward in the end). Therefore, the result is the better competition among religions (or churches), then the higher

\footnotetext{
55 Ibid.

${ }^{56}$ Smith, A. (2004). The Wealth of Nations (Digireads.com Publishing). This theory is usually exclusively known in sociology but has extended in the field of economics and law. Adam Smith first mentioned this theory in The Wealth of Nations. Also see Simpson (1990), The StarkBainbridge theory of religion, in Journal for the Scientific Study of Religion, 29, 361-367.

${ }^{57}$ See Hadden, J. K. (1995). Religion and the quest for meaning and order: Old paradigms, new realities. Sociological Focus, 27, 83-100. See also Warner, S. R. (1993). Work in progress toward a new paradigm for the sociological study of religion in the United States. American Journal of Sociology, 95, 1044-1093.
} 
participation among members or buyers. Therefore, with less choices or competition among religions (or churches), then there is a likelihood of economic instability (Hadden, 1995).

Few studies have focused on constitutionality (or governmental regulation) of religion and how religion influences the market, the happiness index and human rights in general for a nation state. There has been some connection made between official state religion, economic and human development, and religious participation and belief (Barro \& McCleary, 2005).

The results varied, depending on regime type and level of radicalism or hostility towards religion. Essentially, states with official religions that were neither radical nor hostile towards other religions fared well in relation to economic and human development (Hadden, 1995). In fact, from the nation states mentioned in the previous section, Denmark topped the list as being one of the most economically stable and having the least human developmental conflict. This section explores the dynamics as to why one nation state fared better than other nation states.

\subsection{Human Rights Development:}

Research of the most recent human rights development reports indicates that the four nations sampled in this paper have shown significant variance in areas such as gender equality, income, and education. Data compiled from various sources show this to be true, as illustrated in the charts below with explanations that follow. In short, there is a correlation between a nation's gender inequality ranking, its type of regime, and human rights development ranking. 


\section{United Nations Human Reports Development Information}

Compiled from http://hdr.undp.org/en/data

\begin{tabular}{|l|l|l|l|l|l|}
\hline & IHDI & $\begin{array}{l}\text { Human } \\
\text { Rights } \\
\text { Index }\end{array}$ & Health & Education & Income \\
\hline Denmark & $\begin{array}{l}.845 \text { or } \\
(6 \%)^{5}\end{array}$ & 0.90159 & .93 & .92 & .858 \\
\hline France & $\begin{array}{l}.812 \text { or } \\
(9 \%)^{60}\end{array}$ & $.893^{61}$ & .973 & .871 & .843 \\
\hline Iran & & $.742^{62}$ & .839 & .707 & .69 \\
\hline $\begin{array}{l}\text { North } \\
\text { Korea }\end{array}$ & & $\begin{array}{l}\text { No data } \\
\text { provided63 }\end{array}$ & .773 & $\begin{array}{l}\text { No data } \\
\text { provided }\end{array}$ & $\begin{array}{l}\text { No data } \\
\text { provided }\end{array}$ \\
\hline
\end{tabular}

\subsubsection{Denmark:}

Research suggests that minorities in Denmark would enjoy a range of protections not always seen in other nations. The phenomenon found in Denmark's superb rating stems from the low ratio of gender inequality issues. ${ }^{64}$ Gender identity appears to be less of an issue than in other nation states, as the reports show that there is an even ratio between women and men, ${ }^{65}$ along with acceptance of sexual preferences. ${ }^{66}$

\footnotetext{
${ }^{58} 2013$ United Nations Human Rights Development Report, Retrieved from http://hdr.undp.org/en/2013-report. The IHDI shows a difference in ranking of 3.

${ }^{59} 2013$ United Nations Human Rights Development Report, Retrieved from http://hdr.undp.org/en/2013-report. Denmark's ranking among the world's nations is $15^{\text {th }}$.

${ }^{60} 2013$ United Nations Human Rights Development Report, Retrieved from http://hdr.undp.org/en/2013-report. The IHDI shows a different in ranking of -2 .

${ }^{61} 2013$ United Nations Human Rights Development Report, Retrieved from http://hdr.undp.org/en/2013-report. France's world rank is $10^{\text {th }}$.

${ }^{62} 2013$ United Nations Human Rights Development Report, Retrieved from http://hdr.undp.org/en/2013-report. Iran's ranking is $76^{\text {th }}$.

${ }^{63} 2013$ United Nations Human Rights Development Report, Retrieved from http://hdr.undp.org/en/2013-report. Due to the lack of information provided by North Korea to the reporting agency and the numerous international violations, North Korea's ranking is not specified.

${ }^{64}$ United Nations Development Programme, Human Development Reports: Human Development Indicators, Retrieved from http://hdr.undp.org/en/countries/profiles/DNK. As of the date of the 2013 report, Denmark ranks $15^{\text {th }}$ in Human Development among all nations. The indicators range from education to gender equality.

${ }^{65}$ Ibid.
} 
It is not clear if this low ratio of inequality issues result from female monarchial leadership or a combination or sole factor of the parliamentary democratic, the monarchial system, its constitutional provisions on religious rights and/or a state established religious faith of Christianity (The Copenhagen Post, 2013). Whatever the reason, Denmark has met a huge challenge in balancing economic development with human development (The Copenhagen Post, 2013).

Denmark's human development success may result from a combination of factors. The most important piece would be the constitutional provisions protecting religious liberties and beliefs, or the lack thereof (Denmark Constitution). These protections also note, whatever religious belief system, it must be one that upholds good morals and the public order (Denmark Constitution). This latter protection suggests that religious beliefs or the lack thereof must conform to social order that is acceptable and non-hostile (Denmark Constitution.) Regardless if a person is a religious believer, the average individual would feel safe in knowing his or her belief system is protected if it is one of good moral and not against public order (Denmark Constitution).

Another aspect may be Denmark's implementation of a national human rights institute (Denmark Constitution). This institute has been critical in identifying, monitoring and examining human rights issues in its territory (Denmark Constitution).

Finally, because of Denmark's EU membership, the member state also has remedies via the European Court of Human Rights. Therefore, Denmark and its citizens have additional layers of protection relative to human rights concerns.

\subsubsection{France:}

Minorities in France also enjoy similar protections as in Denmark, and research highlights that minorities fare well in France. This indication may be due in part to France's European Union membership that requires certain human rights protections and France's history of societal progression. France ranks $20^{\text {th }}$ in the category of human development. 67 The status of human rights in France has not particularly been an issue,

\footnotetext{
${ }^{66}$ This acceptance of sexual preference is illustrated in the example of a transgendered individual who was granted asylum due to gender identity conflicts. See Jessica Hanley, Trans-woman first in Denmark to be granted asylum based on gender identity, The Copenhagen Post, February 4, 2013 at http://cphpost.dk/news/trans-woman-first-in-denmark-to-be-granted-asylum-based-ongender-identity.4240.html.

${ }^{67}$ United Nations Development Programme, Human Development Reports: Human Development Indicators. Retrieved from http://hdr.undp.org/en/countries/profiles/FRA.
} 
even though it can be said that France has had its share of human rights struggles (which may be considered minor in comparison to other countries).

France has been one of few countries to institute laws protecting not only international human rights but also community rules and regulations. ${ }^{68}$ For instance, women's rights and children's rights have been increasingly important in France; over the years, women participation in government and other sectors have significantly increased. 69

Another example is hate speech. ${ }^{70}$ Such speech is not tolerated in France, and the definition of the term could be extended to conduct, behavior, patterns, and practices. In fact, a noncitizen faces deportation for such acts. ${ }^{71}$ Another notable point is that there are no instances of political prisoners or detainees. ${ }^{2}$

The relevant issues in the human rights forefront in France have been with the migration and integration of individuals within its borders and with prison conditions. 73 Also, there has been a slight increase in AntiSemitic and Anti-Muslim sentiment.74 This increase is attributed to the government eviction of individuals from illegal camps, among other migration issues that have occurred in the past two or three years. 75

There have been few instances of governmental abuses by social forces or officials in authority, There are mechanisms to enforce

\footnotetext{
${ }^{68}$ France has established and recognized human dignity rights including measures recognizing sexual orientation, sexual identity, and protection of human life, as merely three of many examples.

${ }^{69}$ See U.S. Department of State, supra note 133. Women participation in the National Assembly jumped from $18 \%$ to $26 \%$ in 2007 .

${ }^{70}$ Ibid.

${ }^{71}$ Ibid.

72 Ibid.

73 Ibid.

${ }^{74}$ See U.S. Department of State, supra note 133. In recent years, it was reported that 550,000 Jewish people live in France. A 2012 EU Fundamental Rights Agency survey on discrimination and hate crimes in $8 \mathrm{EU}$ member states reported that $21 \%$ of French respondents stated that they had experienced Anti-Semitism, but $79 \%$ stated that they had not. There have been instances in which Anti-Semitic acts occurred, and France, through its local tribunals, and other authorities have been forceful in prosecuting the parties involved to the fullest extent of the law.

${ }^{75}$ See U.S. Department of State, supra note 133. Another aspect that contributes to this AntiSemitic and Anti-Muslim sentiment could result from the anti-religious symbol ban in public educational settings and the inconsistency of French governmental funding of private schools. Again, this has not been the subject of debate, but there could be a connection as to why there is a slight increase in anti-religious sentiment. If this is so, it would be unfortunate, because France appears to be trying to balance the equities, and anti-religious backlash may be unintentional on the part of France's secular laws.
} 
punishment upon governmental abuses as well. 76 Therefore, when human rights violations occur, France has been quick and firm in punishing those in authority responsible, even in recognizing its own violations and following through on EU orders against itself.77

\subsubsection{Iran:}

\section{Balancing human rights and religious influence has been a} challenge in Iran, as Iran has consistently scored in the bottom percentile for human development in recent years. ${ }^{78}$ The Iranian constitution calls for equality and freedom, but the reality of current day Iran is a different reality for many minority groups.79 Despite attempts at passing legislation, there are few processes in which a person can complain about human

\footnotetext{
${ }^{76}$ Ibid. Because France is an EU Member State, it is subject to European Union regulations. Therefore, an individual can file complaints with the European Court of Human Rights. There are also mechanisms on a national level including national and local tribunals, courts and authorities. France itself has mechanisms in enforcing laws that include its own community laws and regulations establishing harsh penalties and punishments for those committing human rights or otherwise national and international law violations: IGS. IGPN, CNCDH, OJP and ING.

77 Ibid.

${ }^{78}$ United Nations Development Programme, Human Development Reports: Human Development Indicators, Retrieved from http://hdr.undp.org/en/countries/profiles/IRN. In 2013, Iran ranked $76^{\text {th }}$ for human development.

${ }^{79}$ Italian Association for Women in Development (AIDOS) presented Gender challenges in Iran, MDGs, Post 2015, education \& employment," a side event at the UN 58th Conference on the Status of Women, on March 12, 2014. Iranian female panelists and scholars spoke about their past and present experiences in Iran. The panelists provided evidence and personal stories on denial of entry into educational programs and their journey to what led them to the UN Conference. The panelists stated that the reality and what is on paper are two different elements. In truth, many times, nations such as Iran send Iranian speakers out to international conferences to give a better view of the gender equality issue when the reality is that the situation is bleak and not equal at all. Some panelists were unafraid to speak the reality of the situation for Iranian women. In fact, the panelists provided a CD with statistical and current evidence of the Iranian women's rights movement and the struggle in gaining equal rights; this disk and the accompanying statistical analysis focused primarily on one region in Iran, the East Azerbaijan province.

The panelists remarked the difference in treatment in Iran varies from other Islamic countries, in part because of interpretation of the Quran. Essentially, the stricter or more traditional view of the Quran, the less rights a women or minority member may have. The panelists also suggested that women had a bigger role in society before the Iranian revolution, which, in the post-revolutionary era, reverted to the traditional view of the Quran, thus dominating society's view. Prior to the Iranian revolution, the leader of the nation at that time developed ties with the western world and opened its doors to more secular practices allowing free trade, movement, and thought of individuals.
} 
rights violations in Iran, unless it is made outside its territory. This would indicate that minorities might not have as many protections as the constitution suggests. One such group is women. 80

Outside of the strict interpretation and religious influence of the Quran, human rights for Iranian women are virtually non-existent. ${ }^{81}$ This is because of many religious interpretative conflicts and political influences. ${ }^{82}$

Women have routinely been denied entry into higher educational institutions, despite taking and passing the entrance exams. ${ }^{8} 3$ In fact, Iranian women have statistically been scoring past the minimum entrance exam score, yet either are denied entry into the institution or desired degree program specialized fields such as medicine or engineering, which have been exclusive to males until recent years. ${ }^{84}$

There are instances in which women have surpassed expectations in degree programs yet are not afforded similar employment opportunities as low-performing male counterparts. ${ }^{85}$ Laws restrict employers' rights to hire certain employees because males are given first preference for the job. 86

Women also face a lack of support from families. ${ }^{87}$ Patriarchal roles throughout society facilitate this lack of support. Families face pressure to support the societal norm-men being the dominant leaders and women being houseworkers and wives (and nothing more)-or being chastised and ostracized in the community for going against that societal norm. 88 Therefore, women are forced to work menial jobs, typically housework, despite the level of education and skill that one possesses. ${ }^{89}$

In recent years, women who have faced these discriminatory practices have sued the institutions for reparations in denying them their human rights of dignity, meaningful work, and the basic right of

\footnotetext{
${ }^{80}$ Ibid.

81 Ibid.

${ }^{82}$ It could be argued that Iran's strict interpretations or practices of the Quran violate international laws on human rights, including the Universal Declaration of Human Rights. Evidence shows (1) women are restricted in education and employment (2) freedom of speech and religion are either limited or banned and (3) cruel and unusual punishment may be commonplace depending on the offense. These indications would violate numerous articles under the UDHR, namely the biggest article, which is Article 1 on human dignity.

${ }^{83}$ See Italian Association for Women in Development (AIDOS), supra note 190.

${ }^{84}$ Ibid.

${ }^{85}$ Ibid.

${ }^{86}$ Ibid.

${ }^{87}$ Ibid.

${ }^{88}$ Ibid.

${ }^{89}$ Ibid.
} 
freedom.90 These cases are still pending and have yet to be resolved.91 There has, however, been hope and promise from the few cases that have been given priority. Proper resolution and recognition have been granted that the women's right has been infringed upon and blatantly denied. ${ }^{2}$

Iran could benefit from a more balanced market approach such as that in the nation states of Denmark and France. Although Denmark has an official state religion, Danish society has been successful in bridging societal divides and upholding good morals, and public order without infringing upon minority rights. France has been successful as well in not officially recognizing one religion over another and protecting the rights of virtually every group or individual.

\subsubsection{North Korea:}

North Korea's human rights record has been an issue for many international organizations and other nations (U.S. Department of State Country Reports on Human Rights Practices, 2011). The country's constitution states that individual rights are a priority and an essential part of its government and society, but the North Korean government neither guarantees nor upholds or even allows them (U.S. Department of State Country Reports on Human Rights Practices, 2011). Ironically, the lack of protection is not isolated to minorities but anyone deemed an enemy of the state or undesired.

In the most recent human rights reports, North Korean citizens have suffered widespread injustices (U.S. Department of State Country Reports on Human Rights Practices, 2011). Under new leadership, North Korea has saw no change in these human rights conditions (U.S. Department of State Country Reports on Human Rights Practices, 2011). In fact, defectors have reported an increase in extrajudicial killings, illegal imprisonment and a blanketed denial of human rights including the right to religious freedom, which is non-existent (U.S. Department of State Country Reports on Human Rights Practices, 2011).

Many North Koreans defect from the region, often choosing various Chinese regions (U.S. Department of State Country Reports on Human Rights Practices, 2011). Statistics reveal at least 70\% of the escapees or defectors are women. North Korea's history denotes one of forced labor (U.S. Department of State Country Reports on Human Rights Practices, 2011), forced marriage and trafficking of persons, mostly being women

\footnotetext{
90 Ibid.

91 Ibid.

92 Ibid.
} 
and children (U.S. Department of State Country Reports on Human Rights Practices, 2011). Complications arise if a defected person is apprehended, because Chinese law requires the return of the defector to North Korea where the defector becomes even more vulnerable to trafficking (U.S. Department of State Country Reports on Human Rights Practices, 2011).

\subsection{Economic Development:}

Religious market theory posits the likelihood that monopolistic religions in a nation weaken religious participation and belief. This debilitation incidentally results in lower economic development. Essentially, when a religion is less competitive and more rigid in nature (i.e., not allowing for other religious belief systems at the same level of participation), the economy may manifest similar indications as well.

In many countries that have not had competitive and open religious aspects, the economic development indicators have lent significant insight into the nation's financial outlook, as shown in the charts below. Subsequent brief explanations and analysis accompany this chart. This analysis focuses on a limited number of indicators-imports, exports, and patents.

\section{Compiled Data on Economic Indicators}

\section{United Nations Human Reports Development Data}

Compiled from http://hdr.undp.org/en/data

\begin{tabular}{|l|l|l|l|l|l|}
\hline & $\begin{array}{c}2010 \\
\text { Exports of } \\
\text { merchandise } \\
\text { goods } \\
(\$ \text { Billions })\end{array}$ & $\begin{array}{c}\text { 2010 } \\
\text { Exports of } \\
\text { merchandise } \\
\text { goods } \\
\text { \% of GDP) }\end{array}$ & $\begin{array}{c}2010 \\
\text { Imports of } \\
\text { merchandise } \\
\text { goods } \\
(\$ \text { Billions })\end{array}$ & $\begin{array}{c}2010 \\
\text { Imports of } \\
\text { merchandise } \\
\text { goods } \\
\text { (\% of GDP) }\end{array}$ & $\begin{array}{c}2010 \\
\text { Exports } \\
\text { of } \\
\text { services } \\
(\$ \\
\text { Billions })\end{array}$ \\
\hline Denmark & 96.5 & 31 & 84.5 & 27.1 & 59.9 \\
\hline France & 511.7 & 19.8 & 592.1 & 22.9 & 143.7 \\
\hline Iran & 83.8 & 25.3 & 54.7 & 16.5 & \\
\hline $\begin{array}{l}\text { North } \\
\text { Korea }\end{array}$ & $\begin{array}{l}\text { Not } \\
\text { available }\end{array}$ & & & & \\
\hline
\end{tabular}




\begin{tabular}{|l|c|c|c|c|c|}
\hline \multicolumn{7}{|c|}{ United Nations Human Reports Development Data } \\
Compiled from http://hdr.undp.org/en/data
\end{tabular}

\begin{tabular}{|l|l|l|l|l|}
\hline \multicolumn{5}{|c|}{$\begin{array}{c}\text { United Nations Human Reports Development Data } \\
\text { Compiled from http://hdr.undp.org/en/data }\end{array}$} \\
\hline & $\begin{array}{c}\text { 2010 } \\
\text { Agricultural } \\
\text { Share of } \\
\text { Imports }\end{array}$ & $\begin{array}{c}\text { 2010 } \\
\text { Manufactured } \\
\text { Share of } \\
\text { Imports }\end{array}$ & $\begin{array}{c}\text { 2010 Parts } \\
\text { and } \\
\text { Components } \\
\text { Share of } \\
\text { Manufactured } \\
\text { Exports }\end{array}$ & $\begin{array}{c}\text { 2010 Parts and } \\
\text { Components share } \\
\text { of manufactured } \\
\text { imports }\end{array}$ \\
\hline Denmark & 16 & 72.7 & 22.1 & 22.8 \\
\hline France & 9.9 & 73.1 & 26.5 & 25.8 \\
\hline Iran & 17.6 & 70 & 4.3 & 21.3 \\
\hline $\begin{array}{l}\text { North } \\
\text { Korea }\end{array}$ & $\begin{array}{l}\text { Not } \\
\text { available }\end{array}$ & & & \\
\hline
\end{tabular}

\subsubsection{Denmark:}

Denmark ranked $15^{\text {th }}$ for human development, and had a relatively stable economy in which imports and exports of goods and services were fairly balanced (United Nations Human Rights Development Report, 2013, 
supra note 162). Unlike its counterparts, Denmark manages to balance its economy without significant dedication to military expenditures (U. N. Human Rights Development Report, 2013). However, an area in which Denmark would be lacking, if at all, is in patent applications (U. N. Human Rights Development Report, 2013). This lack would indicate a need to encourage competitive and creative industries such as the entertainment, medical, and technology industries and to guarantee and enforce intellectual property protections within its region. Some of these efforts, however, have been undertaken via the European Union's uniform markets and regional and international treaties).

\subsubsection{France:}

France ranks $20^{\text {th }}$ in human development but actually fared higher in this economic development category than Denmark (U.N. Human Development Reports, 2013). The difference in both economies could be explained in many ways. First, France is centrally located among other European member states where migration is a daily and constant factor in that region. Second, France's report indicates a wider advantage in patents and innovations compared with Denmark(U.N. Human Development Reports, 2013). France's history of art and its constitutional principles recognizing all individuals, protecting human rights and intellectual property rights could be significant factors, giving France a slight advantage. Coincidentally, these things could contribute to a more highly functioning economy.

\subsubsection{Iran:}

Iran's economic development has been primarily devoted to its own region. Therefore, a complete view or analysis cannot be ascertained, but available information shows that the percentage of imported goods and services is significantly low. Reports show either limited information or incomplete information. Income from imported goods and services is affected by Iran's religious stance and distrust of western principles and civilization.

Although the percentage of imported goods and services is significantly low, there is a high rate of exported goods. However, the rate of exported services and goods could be attributed to the limited employment areas for women laborers, because many products or services are related to household or domestic work. This may be an indicator of the gender inequality issue in that region. 


\subsubsection{North Korea:}

North Korea's economy is not clear from the data researched, given that North Korea has been known to be secretive and hostile in providing governmental and economic data of its region. However, from the reports researched, North Korea has a very high rate of patent applications. In fact, it was the highest among all nations.

This rate would indicate a limited number of factors. First, North Korea has housed several scientific and specialized professionals and entities within its region. That factor could possily relate to North Korea's history of forced labor. Second, North Korea may possibly be generating its economy from said patents, since there are no clear indicators from the governmental reports.

Third, because North Korea has a history and practice in human rights violations and abuses, it is very unlikely that it provides for patent protection, especially if the patent does not benefit the government (i.e., the government has no share or benefit). If this is so, intellectual property infringement are more likely to occur within its borders, while at the same time, those same items are exported to international markets, thereby funneling funds back into North Korea's economy. It must be emphasized, however, that the lack of data makes it impossible to support these contentions, and, particularly, to discern where these patents, products, and funds are flowing.

\subsection{Special Attention to Issues of Economic Development in anti-Religious States:}

Many anti-religious nation states fail to report accurately information to international agencies, yet seemingly desire help from the international community in other instances. Such anti-religious or hostile nation state practices create suspicion and lack of trust in the international community when dealing with that hostile nation state.

Reports of economic development show that anti-religious nation states have a lower economic income threshold than their counterparts. A nation state benefits from having some constitutional provision that recognizes rights to religious belief and/or an official religion that is nonhostile to other religions and customs. The average lifespan may suggest a healthier lifestyle in a few anti-religious nations, but income and quality of measures for minorities indicate otherwise (http://hdr.undp.org/en/countries). 


\section{Conclusions:}

The focus of these conclusions is narrowed to reflect the aim to demonstrate how wholly religious-based constitutions do not necessarily help in keeping social and economic harmony but rather may facilitate disharmony in many aspects. As such, a balance of religious or spiritual aspirations and universality would be beneficial. From the embodiment of international law and the various constitutions reviewed, the following conclusions could be argued:

1. Constitutions that are wholly based on religion do not always yield the best social harmonization. Severe discord remains among social groups. This discord seemingly becomes more intense as these governments institute certain religious stances that apply to the mainstream society.

2. Minority groups seem more restricted in socially and economically deprived regions and nation states.

3. No matter the constitutional structure or form of government of religiously based nation states, minority groups are either notoriously minimized, marginalized and/or lacking in true representative voice in the governmental process.

4. Religion is frequently used as a tool to control social and political order, because it has been an important part in state formation and development.

5. Anti-religious constitutions seemingly do not work in situations that lack democracy and economic stability.

6. Economics and social relations operate hand in hand. Religionbased constitutions can complicate this dynamic if the constitution does not account for equality and protections under the law for those who may or may not follow that religious doctrine.

7. Certain religious ritualistic practices permeate the governmental practice and process of some nation states.

8. Religions are not necessarily progressive and are not always open to current day interpretation. From each generation or shift in societal dynamics, religion offers the least flexibility in adjusting to those societal changes and demands. Essentially, people are vital to a religion in order for doctrines, practices and other values to be followed. Therefore, constitutions should allow room for interpretation and progression, because many social conflicts and minority rights issues begin regarding these issues.

9. Radical institutional norms and values can normalize or control social conflicts to an extent; but, economically, a nation state may not perform at its best. With this in mind, people and businesses 
will not put much effort into work if they are not truly made part of the whole and given consistent, acceptable, and authentic opportunities.

10. Dominant religions tend to become political religions.

11. The core understanding that humankind wants and needs respect, compassion, and peace resonates throughout every society. These principles should be the basis of nation-state constitutions rather than a principal religion.

12. Secular constitutions offer balance, which is one requisite of maintaining social order. However, the nation state may need to offer a voice to minority groups in the political and economic process.

13. Nation states with religious-based constitutions that offer a democratic format and create an inclusive and protective environment for its visitors and citizens offer an effective method to control social order.

14. Nation states, regardless of religious stance, that do not provide for a constitutional framework for grievances and protection of human rights offer the least effectiveness in controlling and protecting social order.

For a nation state to thrive on a global level (i.e., be economically, socially, and culturally stable), it must balance the interests of its territory, people, government, and visitors. A nation state must create, or come close to creating, a secular constitution. Such a constitution need not minimize the core religion of a nation state. Moderation in constitutional rhetoric could benefit a nation. This moderation would necessarily include its constitutional language because interpretations vary. With such moderation, it is possible to create a less offensive and less restrictive societal situation in which people can act humanely and respectfully without compromising morality and individual integrity.

\section{References}

Backer, L. C. (2007). God(s) over constitutions: International and religious transnational constitutionalism in the 21st Century, Mississippi College Law Review, 27, 11.

Barro, R. J. \& McCleary, R. M. (2005). Which countries have state religions? Quarterly Journal of Economics, 12O, 1331-1370. 
Bax, M. (1987). Religious regimes and state formation: Towards a research perspective. Anthropological Quarterly, 6o, 1-11.

Bell, C. (2009). Ritual: Perspectives and dimensions (Rev. ed.). Oxford, UK: Oxford University Press.

Bjerknes Aune, M., \& DeMarinis, V. M. (1996). Religious and social ritual. Albany, NY: SUNY Press.

Brémond, H. (1936). A literary history of religious thought in France from the Wars of Religion down to our own times. London: Society for Promoting Christian Knowledge.

Campbell and Cosans v. UK, March 22, 1983, No. 7511/76, 7743/76, Series A6o. $c f . X v U K$, October 4, 1977, no. 7291/75, D.R. 11 p. 55.

Constitution of Denmark. Oxford constitutions of the world. Accessed December 26, 2014, at http://www.oxcon.ouplaw.com

Constitution of the French Republic: September 28, 1958 (as Amended to July 23, 2008) (France [fr]). Oxford constitutions of the world, Accessed December 26, 2014, at http://www.oxcon.ouplaw.com

Constitution of the Islamic Republic of Iran: October 24, 1979 (as Amended to July 28, 1989) (Iran [ir]). Oxford constitutions of the world, Accessed December 26, 2014, at http://www.oxcon.ouplaw.com

The Danish monarch. Accessed December 26, 2014 at http://kongehuset.dk/english

Fadel, L. (2014). Egypt's crackdown widens, but insurgency still burns. $N P R$, February 10, 2014 available at http://www.npr.org/blogs/parallels/2014/02/10/274670689/egyp ts-crackdown-widens-but-insurgency-still-burns

Hadden, J. K. (1995). Religion and the quest for meaning and order: Old paradigms, new realities, Sociological Focus, 28, 83-100.

Grote, R. (2008). Max Planck Institute, (Ed.). The Democratic People's Republic of Korea: Introductory note. Oxford constitutions of the world. Available at http://oxcon.ouplaw.com/ 
Hanley, J. (2013). Trans-woman first in Denmark to be granted asylum based on gender identity. The Copenhagen Post, February 4, 2013, at http://cphpost.dk/news/trans-woman-first-in-denmark-to-begranted-asylum-based-on-gender-identity.4240.html

Healey, J. (2009). Happy birthday, Declaration of Human Rights, December 8, 2008. Huffington Post. Available at http://www.huffingtonpost.com/jack-healey/happy-birthdaydeclaratio b 149246.html

The Holy Quran. Accessed December 26, 2014 at http://quran.com/1

Horowitz, R. (2010). A detailed analysis of Iran's constitution, Accessed October 12, 2010 at

http://www.worldpolicy.org/blog/2010/10/12/detailed-analysisiran\%E2\%80\%99s-constitution

Indonesia: Rights rollback for religious minorities, women. Human rights watch. Accessed January 22, 2014, at http://www.hrw.org/news/2014/01/21/indonesia-rights-rollbackreligious-minorities-women

Italian Association for Women in Development (AIDOS). (2014). Gender challenges in Iran, MDGs, post-2015, education and employment. Side event session at the UN 58th Conference on the Status of Women, March 12, 2014.

Kertzer, D. I. (1988). Ritual, politics, and power. New Haven, CT: Yale University Press.

Kohlenberger III, J. R. (2005). The contemporary parallel Bible. London: Oxford University Press.

Kohn, G. C. (2007). Dictionary of wars. NY: Infobase Publishing. n.d., http://www.adherents.com/Religions By Adherents.html

Kuru, A. T. (2007). Passive and assertive secularism: Historical conditions, ideological struggles, and state policies toward religion. World Politics, 59, 568-594.

Kuru, A. T. (2009). A research note on Islam, democracy, and secularism. Insight Turkey, 11, 29-40. 
Lerner, H. (2011). Making constitutions in deeply divided societies. ebook accessed 27 January 2014, http://orbis.eblib.com/patron/FullRecord.aspx?p=803129

Lombardi, C. B. (2013). Designing Islamic constitutions: Past trends and options for a democratic future. International Journal of Constitutional Law, 11, 615-645.

Nergelius, J. (2007). Max Planck Institute (Ed.). The Kingdom of Denmark: Introductory note. London: Oxford constitutions of the world. Available at http://oxcon.ouplaw.com/

Nicolle, D. (1984). Arthur and the Anglo-Saxon wars. Colchester Essex, UK: Osprey Publishing.

North Korea: Kim Jong-un Hailed 'supreme commander', December 24, 2011, BBC News, at http://www.bbc.co.uk/news/world-asia$\underline{16325390}$

Pearse, M. (2007). The gods of war. Downers Grove, IL: Inter-Varsity Press.

Religious intolerance and oppression in North Korea. (2004). Accessed December 26, 2014 at http://www.religioustolerance.org/rt nkor.htm

Simpson, J. H. (1990). The Stark-Bainbridge theory of religion. Journal for the Scientific Study of Religion, 29, 361-367.

Smith, A. (2004). The wealth of nations. Digireads.com Publishing.

United Nations Development Programme. (2013). Human Development Reports: Human Development Indicators (2013). Accessed December 26, 2014, at http://hdr.undp.org/en/countries/profiles

United Nations Development Programme. (2013). Human development reports: Human development indicators, 2013. Available at http://www.humanrights.dk/about-us/human-rights-in-denmark http://hdr.undp.org/en/countries/profiles/DNK http://hdr.undp.org/en/countries/profiles/FRA http://hdr.undp.org/en/countries/profiles/IRN 
United Nations General Assembly. Declaration on the Elimination on All Forms of Intolerance and of Discrimination Based on Religion or Belief, November 25, 1981. Accessed December 26, 2014 at http://www.un.org/documents/ga/res/36/a36ro55.htm

United Nations. (2013). Human Rights Development Report. Available at http://hdr.undp.org/en/2013-report

United Nations Human Rights. International Covenant on Civil and Political Rights. Accessed December 26, 2014 at http://www.ohchr.org/en/professionalinterest/pages/ccpr.aspx

U.S. Department of State. Appendix D: Regional organizations' religious freedom commitments. Accessed on December 26, 2014 at http://www.state.gov/j/drl/rls/irf/2008/108547.htm

U.S. Department of State. (2011). Country Reports on Human Rights Practice in 2011 (North Korea). Available at http://www.state.gov/j/drl/rls/hrrpt/2011/eap/186279.htm

U.S. Department of State: Country Reports on Human Rights Practice in 2013 (France), 2013, at http://www.state.gov/j/drl/rls/hrrpt/humanrightsreport/index.ht $\underline{\text { m? year }=2013 \& \mathrm{dlid}=220279}$

U.S. Department of State. (2013). Human Rights (North Korea). Available at http://www.state.gov/p/eap/ci/kn/humanrights/index.htm

Universal Declaration of Human Rights, G.A. res. 217A (III), U.N. Doc A/810, 1948.

Warner, S. R. (1993).Work in progress: Toward a new paradigm for the sociological study of religion in the United States, American Journal of Sociology, 95, 1044-1093.

Brandy G. Robinson received her first law degree from Thomas M. Cooley Law School and her next law degree (LL.M. in Transnational Law) from Willamette University. She is currently an adjunct for various educational institutions teaching subjects ranging from law, criminal justice, history, to other liberal arts subject matter areas. 